\title{
SOBRE A CRISTIANIZAÇÃO DA LUSITÂNIA: NOVAS REFLEXÕES A PARTIR DOS DADOS HISTÓRICOS E DAS EVIDÊNCIAS ARQUEOLÓGICAS ${ }^{1}$
}

\section{About "The Christianization" of Lusitania: new reflections from the historical information and the archaeological evidences}

\author{
André Carneiro ${ }^{2}$
}

Recibido el 21 de marzo de 2009. Aceptado el 30 de abril de 2009.

\begin{abstract}
Resumo. Apresentam-se algumas reflexões a partir do estado dos conhecimentos existentes sobre as primeiras manifestações das comunidades cristãs no território da Lusitânia. Em face das informações literárias e dos novos dados trazidos pela Arqueologia procura-se delinear um quadro evolutivo desta problemática, identificando os fenómenos de adesão e os factores de resistência ao longo da Antiguidades Tardia. Palavras chave: Antiguidade Tardia; Cristianismo; Villae.
\end{abstract}

Resumen. En este trabajo se presentan algunas reflexiones a partir del estado de los conocimientos existentes sobre las primeras manifestaciones de las comunidades cristianas en el territorio de Lusitania. Manejando la información de las fuentes literarias y los nuevos datos proporcionados por la Arqueología esbozamos un cuadro evolutivo de esta problemática, identificando los fenómenos de adhesión y los factores de resistencia durante la Antigüedad Tardía.

Palabras clave: Antigüedad Tardía; Cristianismo; Villae.

Abstract. In this paper we present some reflections derived from the current knowledge on the first manifestations of Christian communities in Lusitania's territory. We outline an evolutionary frame of this problematics, identifying the phenomena of adhesion and the factors of resistance during the Late Antiquity by handling the information of literary sources and the new data provided by Archaeology.

Key Words: Late Antiquity; Christianity; Villae.

\section{O PANORAMA LIDO A PARTIR DAS FONTES}

Um momento tão decisivo para a História da Humanidade como o colapso do Império Romano necessariamente produziu ao longo dos tempos uma ampla bibliografia e intensas discussões científicas. Todavia, em todos os olhares que sobre essa época foram lançados podemos encontrar apenas duas perspectivas.
Uma, mais tradicional, na linha da visão catastrofista que nos deixaram os historiadores cristãos do século $\mathrm{V} \mathrm{e} \mathrm{VI,}$ que nos fala do impacto causado pelas invasões bárbaras e pelo fim da civilização, com epicentro em Roma, mas com uma magnitude que atingiu todos os pontos do Império. 0 lento e inexorável declínio do Império na sua fase final foi abruptamente cortado pelas Invasões Bárbaras, que precipitaram a civilização então conhecida na longa noite medie-

(') 0 presente artigo resulta da passagem a escrito da comunicação A Cristianização da Lusitânia: entre os dados históricos e as evidências arqueológicas. apresentada pelo autor no "Congreso Internazionale Portogallo e Mediterraneo", realizado em Nápoles em 2007. Por limitações de espaço, o texto entregue para publicação nas respectivas actas deixou à margem algumas reflexões e informações julgadas importantes e que agora aqui se apresentam com maior desenvolvimento.

(2) Departamento História. Universidade de Evora. Correo electrónico: ampa@uevora.pt 
- FiguRa 1. Localização genérica da área em análise na Península Ibérica

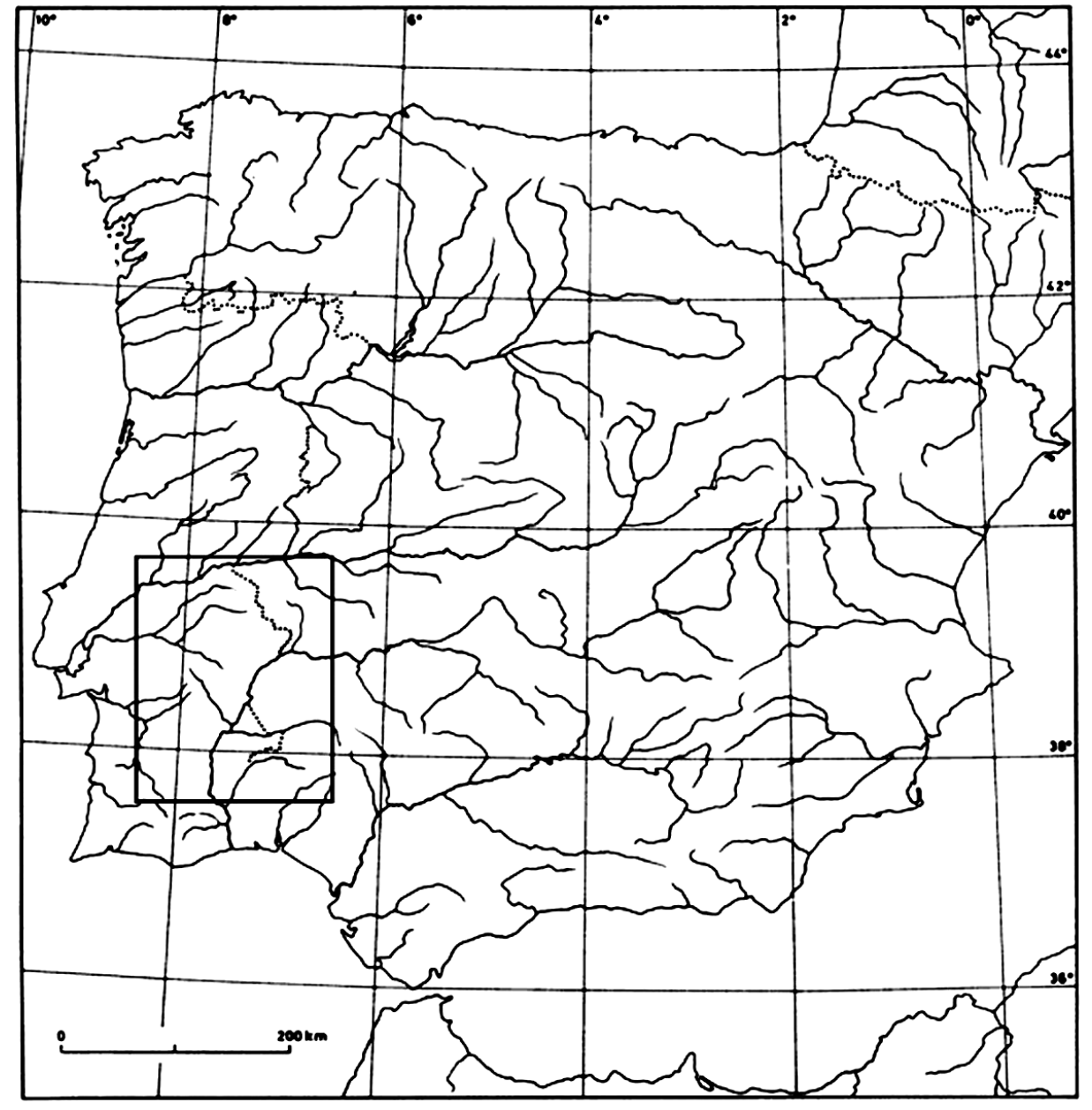

val. Esta perspectiva de Decline and Fall apresenta o seu emblema máximo na obra de Edward Gibbon, paradigma da tradicional leitura deste período.

Em meados do século $X X$ a produção historiográfica empreende uma viragem. Em 1936 Henri Pirenne propunha uma continuidade no processo civilizacional ${ }^{3}$, colocando a tónica no modo como a ideia de Império continuou a subsistir e a dominar o imaginário europeu durante os séculos seguintes. Embora sem esquecer a ruptura política, importava não apagar os nexos de persistência que continuavam a marcar 0 quotidiano, nos mais variados domínios da vivência social. Se não se podem negar as evidências que apontam para fortes quebras com o mundo anterior, convém não subestimar as marcas de continuidade que se prolongam para as épocas seguintes. Assim, mais do que em ruptura, deveriamos antes falar de um processo histórico onde os feixes de resistência devem ser valorizados ou onde as grandes estruturas de organização da sociedade não eram abaladas pelas ondas de choque na esfera política e militar.

$\mathrm{Na}$ Península Ibérica, o desenvolvimento da actividade arqueológica na década de noventa, a par com uma maior definição dos critérios estratigráficos na escavação arqueológica, e ainda com um progressivo melhor conhecimento dos quadros tipológicos em certas famílias cerâmicas (nomeadamente na terra sigillata africana, a cerâmica de importação cujo fabrico se prolongou até ao século VII) permitiu começar a definir com mais precisão os diversos momentos finais de ocupação nas villae romanas. E surpreendentemente, ou talvez não, com cada vez maior intensidade e frequência os dados apontavam para um espectro cronológico durável, atingindo o momento da conquista islâmica, e pontualmente registando momentos de ocupação mesmo para lá do século VIII sem que se registassem alterações fundamentais no quotidiano. Raros são os níveis de destruição documentados, mantendo-se um considerável fluxo comercial de importação e de circulação de gentes e produtos.

Esta perspectiva que sublinha a continuidade nos códigos de organização da vivência quotidiana face às alterações das conjunturas políticas, de acordo com uma leitura estruturalista de grande fôlego, foi re-centemente reequacionada com o já fundamental estudo de Ward-Perkins (2006), que voltou a colocar a acentuação no radical retrocesso civiliza-

(3) Mahomet et Charlemagne, Bruxelas, Nouvelle Sociéte de l'Édition. Foi utilizada a edição portuguesa de 1992. 
cional para níveis protohistóricos e para o completo colapso de um conceito fundamental no mundo romano: o conforto, no mais amplo sentido da palavra ${ }^{4}$.

Entre a visão da historiografia tradicional e as novas perspectivas com o aparente suporte da Arqueologia temos, portanto, duas situações distintas. Desta forma, o que devemos valorizar: a visão catastrofista das fontes ou os nexos de continuidade sugeridos pelos dados da cultura material? Ou poderemos definir patamares intermédios entre as duas leituras?

\section{OS DADOS FORNECIDOS PELOS TEXTOS HISTÓRICOS}

A documentação produzida na época e que está disponível para análise assenta sobretudo em três grandes campos de origem:

- Textos e crónicas de carácter histórico e narrativo;

- As actas de concílios e reuniões eclesiásticas;

- Relatos das vidas e feitos dos primeiros mártires cristãos.

\subsection{Os textos da época}

As fontes existentes para a época são escassas, com o problema acrescido do desequilibrio existente: os primeiros indicadores encontram-se no século III, mas em seguida temos uma quebra nos séculos IV e $V$, à qual se segue um progressivo aumento de referências a partir do século VI. Mais ainda, os textos que chegaram até nós são de valor desequilibrado, sendo a maior parte de produção cristã, oferecendo-nos portanto uma leitura ideologicamente comprometida que enfatiza o declínio teleológico da cultura pagã e o "barbarismo" dos povos que se começam a estabelecer no território do Império.

Em termos gerais, durante o século II o Cristianismo conhece uma fulgurante expansão ao longo de toda a bacia do Mediterrâneo. Para o cidadão de crença pagã, a coragem dos mártires cristãos impressiona, produzindo um efeito contrário ao pretendido pelas autoridades. Em meados do século, durante as convulsões militares e as sucessivas pestes, crises económicas e fomes, as comunidades cristãs são as únicas que permanecem unidas, substituindo as autoridades estatais na vida quotidiana.

Desta forma, o Cristianismo vai ganhando adeptos entre as comunidades urbanas, com necessários reflexos no número de referências documentais que com a passagem do tempo vão sendo mais numerosas. Entre 182 e 188, Ireneu, Bispo de Lyon ${ }^{5}$, fala-nos de comunidades cristãs em expansão na Hispânia; vinte anos mais tarde, Tertuliano diznos que o Cristianismo, ao contrário do Judaísmo que permaneceu "acantonado em Jerusalém", espalhouse por todo o mundo, incluindo a Hispânia ${ }^{6}$. Nos centros urbanos, de forma lenta, mas imparável, o Cristianismo vai ganhando adeptos e criando uma estruturação hierárquica que lhe permitirá ser a âncora social ao longo dos diversos tempos de crise.

Após o Édito de Constantino, em 313, que promulga a liberdade religiosa, o número de referências documentais para a expansão do Cristianismo na Península aumenta à medida que a Igreja se vai consolidando. No Século IV, as crónicas de Sulpício Severo, que apresentam um resumo da história da Igreja até 400, dãonos uma leitura clara da progressiva hierarquização do culto. Em âmbito mais alargado, Eusebius de Cesarea deixounos na História Eclesiástica o mais antigo relato, desde os inícios da Igreja católica, até à queda de Licinius em 324. Lactantius escreveu uma obra sobre as perseguições aos cristãos entre 303-313, De Mortibus Persecutorum, particularmente útil para conhecermos os primeiros mártires cristãos. Para o século seguinte, Idácio, no seu Chronicon, relatanos os acontecimentos entre 379 e 469, deixando-nos o retrato de uma comunidade florescente, assumindo uma dinâmica cada vez mais relevante na vivência colectiva.

A partir do século VI já os testemunhos começam a ser numerosos: Isidoro de Sevilha, Gregório de Tours, e em especial, a obra de São Martinho de Dume ${ }^{7}$, que é particularmente interessante para melhor percebermos o que se passa nos campos do Ocidente peninsular. 0 De Correctione Rusticorum recomenda aos habitantes dos campos que frequentem as ecclesiae e os loca sanctorum, entendendo a evangelização no ambiente rural como a grande tarefa que o Cristianismo deve agora, nesta nova fase, realizar. Esta intenção indica-nos que o culto pagão ainda prosseguia com alguma actividade, em templos rurais situados nos montes e nos bosques ou em todos os territórios periféricos mais distanciados das cidades. A sua obra expressa também grande atenção à implantação de comunidades monásticas que poderão servir como uma guarda avançada do Cristianismo, ou seja, tornase vital a fundação de pontos a partir dos quais a mensagem cristã pode ser emitida em permanência para as comunidades envolventes e onde, os monges, pelo seu exemplo de trabalho e dedicação, podem captar novos fiéis. Ganhas as cidades, iniciase a conquista dos campos.

\subsection{A progressiva organização hierárquica}

A informação resultante dos concílios é particularmente útil por dois motivos: pela indicação de proveniência dos participantes, o que nos fornece indicações sobre a geografia do culto, com o surgimento de uma cristandade progres-

( ${ }^{4}$ Sobre este periodo consultese também as obras de dois autores fundamentais: Brown (1978; 1995) e Cameron (1998).

(5) Aduersus Haereses, I: 10

(6) Aduersus Judaeos, 7.

(7) Maciel 1996: 67-70. 
sivamente mais organizada; e pela leitura das suas actas, que nos permitem perceber quais as preocupações e os combates que concentravam a atenção do episcopado.

A primeira referência documental surge na já bem conhecida epístola 67 de Cipriano de Cartago, no ano de 254, em que se menciona a existência de uma comunidade cristã com uma estruturação hierárquica em Mérida, sob a liderança de um bispo. Esta referência é particularmente preciosa pois deixa subentender que, mesmo durante um periodo de fortes perturbações na geoestratégia do Império, na capital da Lusitânia tínhamos já um conjunto de fiéis bem organizado, com um local de culto que servia como ponto de confluência e reunião de distintas gentes.

Para o século IV a qualidade da informação aumenta, pois temos conhecimento das primeiras reuniões eclesiásticas, uma vez que decorrem concilios em três ocasiões ${ }^{8}$. 0 de Iliberri, reunido em 308 é particularmente revelador, pois reuniu 19 bispos e 24 presbiteros, incluindo representantes de Évora, Faro e Mérida. Com a passagem do tempo, não apenas aumenta a frequência dos concílios (atravessando um período durante o século $\mathrm{V}$ em que as perturbações forçaram a interrupções no seu funcionamento), como também o âmbito geográfico dos presentes. Progressivamente vamos notando a comparência de enviados de novas comunidades, embora sempre mais centradas na zona Sudeste da Península (a região mais povoada e aberta aos influxos comerciais e às trocas de gentes e ideias que tal actividade implica) e nos centros urbanos axiais em relação às grandes vias terrestres.

A dinâmica cristã na Lusitânia é assegurada pelo activo papel da capital, Augusta Emerita. A sua centralidade nos tempos finais do Império é comprovada pela existência de um vicarius hispaniarum que implicava a presença de um officium muito numeroso, uma "enorme cantidad de burócratas [que] constituían una militia non armata, y eran la esencia misma

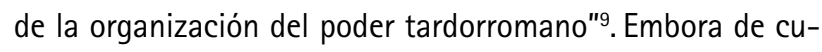
nho pagão, e por isso conservador, a existência na cidade de uma elite altamente qualificada, culta e atenta aos fenómenos emergentes permitiu que a manutenção das dinâmicas comerciais e culturais trouxesse para a cidade um conjunto de novas gentes e ideias. Por isso, embora pequena em termos numéricos, começa a reunir-se uma activa comunidade de fiéis que em breve irá transformar de forma radical a topografia cultual da cidade. Em 308 o bispo Libério está no concilio de Iliberri, e em 314 no de Arles, sendo na ocasião o único hispano, o que não deixa de ser significativo. Se para o período entre a segunda metade do século IV e primeira do V as dinâmicas urbanas de Mérida são confusas e mal conhecidas, o retrato que nos surge nos inícios da centúria seguinte é o de uma cidade que conseguiu resistir às perturbações políticas e que apresenta uma comunidade cristã pujante, alicerçada em torno do culto a Santa Eulália e conservando a sua autonomia mesmo face à implantação da corte visigoda em Toledo, para o que beneficiou de uma sequência de líderes espirituais extraordinariamente activos e carismáticos ${ }^{10}$.

Infelizmente, o panorama para outros núcleos urbanos do actual Alentejo é absolutamente desconhecido.

As sucessivas campanhas de escavação realizadas na cidade de Ammaia ainda não foram publicadas, pelo que não é possível confirmar a informação de Isa Ibn Ahmad arRázi sobre a "Amaia-das-Ruinas", no sopé da elevação onde IbnMaruán fundou Marvão, que indirectamente nos indica que no século $X$, embora abandonada, a cidade era ainda um referente geográfico importante. Para o final do Império, as notícias existentes apontam para "um período de estabilidade ou mesmo prosperidade"11 que durante algum tempo ainda foi mantido até ao abandono definitivo no século VII.

Para Évora não deixa de ser bizarro que não haja o mínimo conhecimento sobre a evolução tardia da cidade, isto em face da tradição de investigação e das numerosas intervenções arqueológicas realizadas a partir dos anos oitenta. Esta intensa actividade ainda não permitiu libertar informação de âmbito urbanístico, arquitectónico ou artefactual, o que é fortemente contrastante com as informações literárias que nos falam de mártires e bispos em grande acção evangelizadora.

Sobre Beja existe um importante núcleo de elementos arquitectónicos paleocristãos (estranhamente ausentes em Évora ou Ammaia) que nos alerta para a existência de espaços cultuais em relativo numero e com assinalável qualidade decorativa. Mas sobre a cidade, e embora se refira à Pax Iulia imperial, são válidas as palavras de Conceição Lopes, pois "apesar da grande quantidade de vestígios [....] pouco ainda se sabe $[. . .]^{12 "}$, ou seja, os indicadores existentes são fruto sobretudo do labor coleccionista individual e de algumas intervenções mais recentes feitas ao sabor das contingências da Arqueologia Urbana mas sem uma clara estratégia de conjunto que permita homogeneizar a informação.

Apesar da carência de dados materiais, o panorama que surge parece ser o de um mundo urbano em transformação a partir do século IV (ou mesmo já desde o III), no qual as comunidades cristãs vão progressivamente organizando a vivência urbana. Embora as informações para o século V e VI sejam escassas, será durante este período que assistimos a uma consolidação destas estruturas que permitem que o movimento seguinte seja o da conquista dos agrii rustici, em certos casos a partir de aglomerados que já possuem a dignidade de sedes episcopais, o que indirectamente nos indica

$\left({ }^{8}\right)$ Para estas e outras referências ver em especial Jorge 2002: 99102 e anexo I.

(9) Arce 2002: 16.

$\left({ }^{10}\right)$ Cujas biografias laudatórias surgem nas Vitas Sanctorum Patrum emeritensium.

(11) Pereira 2005: 63

(12) Lopes 2003: 204 
a vitalidade deste movimento. No entanto, o facto de pelo caminho terem sido abandonadas cidades (ou pelo menos terem existido fortes retracções na área ocupada) alertanos para as diferentes direcções deste percurso.

\subsection{Santos e mártires na construção da paisagem}

Para a Lusitânia, as referências a martírios de figuras profundamente vinculadas à fé cristã são relativamente numerosas, o que nos permite ter uma imagem do que seria a pregação e a difusão da mensagem a partir do século IV. É de notar no entanto que em muitos casos é difícil perceber a credibilidade histórica do relato, seja porque este foi elaborado a vários séculos de distância, recebendo uma espécie de tratamento mitográfico e laudatório que se acentua com a repetição e com a passagem do tempo, seja porque encontramos certas fórmulas literárias que se vão sistematicamente repetindo ou são, claramente, artifícios de estilo ${ }^{13}$.

As primeiras referências a mártires são provenientes de meios urbanos, embora a sua existência histórica não esteja comprovada e em alguns casos seja mesmo duvidosa: Eulalia de Mérida, os irmãos Julia, Maxima e Verissimus de Lisboa, Vicente, Sabina e Cristeta em Ávila ou Talavera de la Reina e Mansius em Évora. Temos ainda outras referências associadas, como os "mártires da Tourega", Santa Celerina e São Brissos (que prestaram as últimas exéquias a São Torpes), São Jordão e São Brissos, todos de Évora.

Tomemos o caso de São Manços como exemplo mais significativo, até pela simbólica local que ainda hoje detém. A descrição da Passio respectiva informanos do seu martírio, no século VI, às mãos dos proprietários rurais que detinham um latifúndio algures na zona de Évora e para quem trabalhava. Os seus senhores eram judeus e forçaramno sem sucesso à conversão para a sua religião. 0 seu corpo foi abandonado, mas mais tarde a propriedade muda para as mãos de cristãos, que o irão localizar e lhe oferecem um sepulcrum condigno, sobre o qual se edifica um templum inicialmente modesto. Com o tempo o local ganha tal relevância que se transforma em centro de peregrinação, o que leva a sucessivas reformulações. No século VIII já merece duas basílicas e um baptistério, estando todo o recinto murado e monumentalizado ${ }^{14}$.

A progressiva edificação do seu sepulcro, que constitui simultaneamente local de culto mas também de paragem e ainda de estruturação de uma nova geografia religiosa em construção, é portanto um exemplo de outras situações - como o bem conhecido caso de Santa Eulália, em Méridaque poderão ter ocorrido em outros pontos, mas para as quais não temos ainda uma suficiente correlação entre os dados históricos e arqueológicos. Lugares que se irão transformar em marcos axiais nas novas hierarquias dos territórios, em pontos congregadores da comunidade pelo seu papel de centro de convergência e de reunião de fiéis.

No território eborense temos outro núcleo documental muito interessante na referência aos mártires da Tourega, importante villa situada próximo de Évora. Na descrição do seu martírio, lê-se: "No anno de 305 veyo a Evora o Presidente Daciano, que noticioso dos innueraveis sujeitos, que abominavaõ as suas idolatrias, e publicavaõ claramente as verdades Catholicas, os fez prender, e levar para huma quinta de recreaçaõ, que tinha com hum magnifico Palacio, de que hoje se vem vestigios no lugar da Ourga, que fica em doas legoas de distancia da Cidade de Évora"15.

A presença destes lugares de memória ligados a martírios teve ainda uma outra função, em plano estritamente simbólico. A presença dos martyria constituía um factor de ligação directa entre o indivíduo e a esfera divina através de um intermediário que, ao contrário das entidades sobrenaturais das religiões pagãs, fôra de carne e osso, tal como o crente. Este factor é acentuado pela circunstância de muitos deles lugares sagrados albergarem relíquias, as provas tangíveis da materialidade da figura ${ }^{16}$. Ou seja, mártires, nesta primeira fase, e santos, depois, são mais autênticos, mais tangiveis do que os numina ou do que os genia antigos, e nesse sentido a sua vinculação a um lugar concreto foi um elemento de magnetismo favorável à estruturação de uma nova paisagem religiosa.

\section{AS MARCAS NA PAISAGEM}

A hagiotoponímia é um mundo complexo, que nos fornece um amplo lote de informações mas que no entanto devem ser manuseadas com grandes precauções. Ao analisá-la não devemos supôr automaticamente a existência de nexos de continuidade entre o sítio pagão e o templo cristão que geralmente se lhe sobrepõe. Na verdade, é necessário perceber a existência de três momentos fundamentais e diferenciados neste processo ${ }^{17}$ :

(13) Com a função de exaltar a virtude ou o sofrimento da personagem em causa. Um exemplo são os "santos cefalóforos", que após a decapitação recolhem a cabeça e continuam a pregação. Muitas vezes estas fórmulas literárias são de alguma forma decalcadas da mitologia clássica. 0 exemplo mais emblemático poderá ser o da "viagem", de um périplo (por vezes com contornos épicos) cumprido pela personagem que acaba por exaltar a sua virtude e que deve servir de modelo inspirador para peregrinos e crentes cumprirem o mesmo percurso. Sobre as fontes existentes na Lusitânia para este periodo, ver em especial Jorge 2002, e Velazquez 2005 (em especial o útil apêndice à primeira parte, 124-137).

(14) Maciel 1996: 100-102.

(15) Aranha 1761: 203.

(16) Situação que conferia uma acrescida importância ao templo, na medida em que para a sua consagração era necessária a anuência da lgre$\mathrm{ja}$, conferindo um estatuto ao local. Simultaneamente, o mártir torna-se patrono e protector da estrutura e dos fieis que a demandam.

(17) Retomo o que já escrevi em Carneiro 2002: 148-149. 
- Durante os momentos finais do Império, acompanhando os primeiros influxos cristãos. De um modo geral, a hagiotoponímia para este período perdeu-se, ou seja, não sabemos qual a invocação destes templos, que em muitos casos foi alterada posteriormente;

- Ao longo dos séculos VII/VIII, antes das invasões muçulmanas. Para esta fase, os templos paleocristãos são escassos na região e, de um modo geral, encontramse por estudar;

- Após a Reconquista cristã, e até ao século XIV. São as invocações mais ricas de conteúdo e mais significativas, pois a criação de uma nova topografia religiosa realizada após o domínio islâmico foi um processo de maior profundidade do que aquele que geralmente tem sido considerado.

De um modo geral, a atribuição de um topónimo de um santo arcaico, de um mártir ou figura sacra pertencente aos primeiros séculos da Era, denuncia a cristianização de lugares pagãos. A invocação do santo ajudanos a perceber o fenómeno que ali teve lugar e a caracterizar o sítio anteriormente existente, quer a nível do seu perfil de ocupação, quer na sua implantação topográfica na paisagem. Todavia, não significa (nem tal podemos inferir de forma automática) uma continuidade de prática religiosa no local, onde uma capela ou ermida reveste e reformula um culto anterior perpetuando a vivência do local. Cardim Ribeiro ${ }^{18}$ já procedeu à desconstrução do mecanismo para o caso mais marcante, o do Santuário de Endovélico, onde em momento posterior, e desligado do santuário pagão (até espacialmente), foi fundada a capela de S. Miguel da Mota. Ora São Miguel é simultaneamente aquele que vence a "serpente" -entendida como o Mal, ou uma figuração do "pagão"-, mas o santo arcanjo compreende igualmente atributos médicos (é entre nós o patrono dos boticários, e o santuário deveria ser um local de cura) e ainda atributos psicopompos (é ele quem pesa as almas), sendo adorado, por tradição, em altos lugares. Esta situação também se deve ter registado em S. Miguel de los Fresnos (Badajoz), onde, de modo significativo, terá existido um outro santuário de culto a Endovélico. Volto no entanto a sublinhar que este processo não significa uma continuidade cultual do lugar, que aliás tem sido arqueologicamente negada. É de facto muito provável que o outeiro tivesse atravessado um momento de "satanização do locus sacer de Endovellicus - ou seja, a sua transformação num lugar interdito, danado, apenas frequentado 'clandestinamente' e a horas mortas para práticas ocultas ora tidas por demoníacas"19.

0 que significa sim, é que mesmo atravessando um período de ausência, os referentes simbólicos associados às vivências anteriores dos espaços enformaram e conduziram as motivações cristãs para atribuições hagionómicas específicas, funcionando como marcadores referenciais da paisagem global. E nesse sentido não devem ser ignorados, até pela existência de padrões recorrentes, embora seja necessário confirmar a existência de ocupações anteriores nos locais e a evolução da designação ao longo da diacronia.

A mesma relação encontramos em topónimos como São Bartolomeu, cujo martírio, que lhe conferiu o atributo da faca, consistiu no seu esfolamento, o que, tendo em conta a "mudança de pele», faz dele também um santo invocado em lugares onde se deu uma conversão da divindade pagã primitiva ao cristianismo.

Já em lugares de invocação a São Martinho (que simbolicamente entregou a túnica, ou seja, deixou de se vestir e de se comportar como um pagão), São Romão (em lugares pagãos de origem romana, dos "romãos") e São Pedro (geralmente em lugares de passagem, de "transferência") temos sítios de tipo "villae", com implantação a meiaencosta, próximo de bons solos agrícolas. Trata-se geralmente de lugares de planície, onde podemos perceber a cristianização do local, ou da ruína, obliterando o passado e reinscrevendo o lugar na nova geografia territorial.

Um campo específico muito relevante reside nas invocações relacionadas com o gado, e por extensão, com a transumância e os cultos de fertilidade: São Cornélio, São Marcos, São Saturnino, Santo Isidro possuem ligação a canadas de gado e a importantes vias, estando geralmente nas proximidades de villae ou de lugares de maiores dimensões.

Temos portanto as seguintes situações, nas quais podemos entrever as relações entre os hagiotopónimos, a possível funcionalidade dos sítios arqueológicos e a sua implantação topográfica:

\begin{tabular}{|l|l|l|}
\hline \multicolumn{1}{|c|}{ Nome } & \multicolumn{1}{|c|}{ Atributos/Relação } & \multicolumn{1}{c|}{ Tipo de sítios } \\
\hline S. Miguel & $\begin{array}{l}\text { Aquele que vence a } \\
\text { serpente }\end{array}$ & $\begin{array}{l}\text { Elevações de grande } \\
\text { destaque com } \\
\text { povoados de altura }\end{array}$ \\
\hline S. Romão & Semelhança toponimica & Villae \\
\hline S. Martinho & Entrega das vestes & $\begin{array}{l}\text { Elevações de grande } \\
\text { destaque com } \\
\text { povoados de altura }\end{array}$ \\
\hline S. Saturnino & $\begin{array}{l}\text { Martírio por touro - } \\
\text { ligação a festas do gado }\end{array}$ & Villae \\
\hline S. Pedro & $\begin{array}{l}\text { Zonas de passagem, } \\
\text { de transição }\end{array}$ & $\begin{array}{l}\text { Villae, geralmente com } \\
\text { larga diacronia }\end{array}$ \\
\hline S. Lourenço & $\begin{array}{l}\text { Semelhanças } \\
\text { toponímicas }\end{array}$ & $\begin{array}{l}\text { Elevações de grande } \\
\text { destaque, com } \\
\text { povoados de altura }\end{array}$ \\
\hline S. Cornélio & $\begin{array}{l}\text { Semelhanças } \\
\text { toponímicas }\end{array}$ & Villae, Rochedos \\
\hline
\end{tabular}




\begin{tabular}{|l|l|l|}
\hline S. Marcos & $\begin{array}{l}\text { Festas agrícolas e } \\
\text { bênção do gado }\end{array}$ & Villae; vias \\
\hline S. Isidro & $\begin{array}{l}\text { Festas agrícolas e } \\
\text { bênção do gado }\end{array}$ & Villae; vias \\
\hline S. Bartolomeu & $\begin{array}{l}\text { Martírio - "mudança } \\
\text { de pele" }\end{array}$ & Villae \\
\hline S. Antão & Eremitismo & $\begin{array}{l}\text { Ermidas em povoados } \\
\text { de altura }\end{array}$ \\
\hline S. Gens & Eremitismo & $\begin{array}{l}\text { Ermidas em povoados } \\
\text { de altura }\end{array}$ \\
\hline
\end{tabular}

Nas invocações atribuídas encontramos conteúdos simbólicos que permitem rastrear informação referente à possível existência, funcionalidade e implantação topográfica de um sítio anterior. No entanto, é indispensável tomar algumas precauções: nunca ceder à tentação das generalizações; confirmar sempre in situ a existência, ou não de um local de anterior ocupação; e sobretudo, evitar as leituras neo-paganistas, pois nem sempre uma invocação cristã reveste um fenómeno anterior, não esquecendo que em todo este processo existem várias fases, distintas etapas e diversas motivações. Para mais, no espaço alentejano faltam-nos duas coordenadas fundamentais que, face às irregularidades da pesquisa, ainda não conhecemos exaustivamente: o tempo (os momentos de atribuição da invocação) e o espaço (numerosas zonas ainda sem informação do ponto de vista arqueológico). Sem sistematicidade da pesquisa é difícil estabelecer padrões fiáveis de leitura.

\section{O CONTRIBUTO DA ARQUEOLOGIA}

\subsection{As villae: evoluções finais e reconversões}

Vamos deixar a análise dos padrões de povoamento para outra ocasião e vamos centrarnos na leitura dos parâmetros de mudança no interior dos sítios arqueológicos conhecidos.

É necessário ter em consideração que, no estudo das villae rurais, os momentos compreendidos entre os séculos IV e VIII têm sido insuficientemente trabalhados, por duas questões estratégicas essenciais.

Por um lado, porque o intuito da generalidade das equi- pas que realizam intervenções nos sítios é o de identificar as realidades altoimperiais, geralmente associadas ao "momento de apogeu", com tudo o que isso implica do ponto de vista arquitectónico e artefactual. Ou seja, em especial em escavações realizadas em épocas mais antigas, a informação contida nos niveis estratigráficos superiores era geralmente subvalorizada em função daquilo que se esperava encontrar sobre os pavimentos de mosaico que tantas vezes constituiam o fim último dos trabalhos.

Em segunda ordem, mas de forma indissociável, a dificuldade de reconhecer as realidades materiais desse momento levaram à sua subalternização face à cultura artefactual alto-imperial, com quadros de referência mais bem definidos e tipologicamente agrupáveis. Por estes motivos encontramos para a Lusitânia, ou uma incómoda ausência de informação, ou escassas notícias fragmentadas que apenas nos permitem antever o que poderia ser um rico arsenal de informação para os momentos finais das villae ${ }^{20}$.

As transformações documentadas nos sectores residenciais, ou seja, na pars urbana, processamse em várias direcções, reflectindo possivelmente a própria heterogeneidade dos distintos fácies dos pontos de povoamento que genericamente, mas de forma demasiado simplista ou linear, designamos como villae ${ }^{21}$.

A mais frequente no mundo mediterrânico, embora escassamente documentada na Lusitânia, consiste na reconversão dos espaços nobres em zonas de actividades económicas $^{22}$. Estas são de âmbito variado: observamos que a antiga pars urbana é reocupada como zona de lagar, como área de armazenamento usando dolia ou silos, ou então nesse espaço são instalados fornos de produção cerâmica. Nestas diversas situações muitas vezes as amplas divisões são compartimentadas em espaços mais pequenos, com alterações que inclusivamente destroem os pavimentos de mosaico.

Em outros casos temos a reconversão da pars urbana em necrópole. Na villa da Terrugem (Elvas), Abel Viana documentou que "as sepulturas rodeiam por três faces os alicerces de um grande edifício de planta rectangular, quase quadrada, feitos de blocos de granito", distinto de um outro, que poderá ter funcionado como mausoléu, que na base tinha

$\left.{ }^{20}\right)$ Situação que não apenas é válida para a Antiguidade Tardia mas também se sente de modo agudo para o periodo de presença muçulmana. Em numerosos sítios arqueológicos em meio rural (penso, por exemplo, na zona de Beja, onde há numerosos casos, como Monte da Salsa, Pisões, Cidade das Rosas, Vale de Aguilhão, ...) existem achados soltos de informação relativa ao século VIII em diante que infelizmente não podem ser devidamente contextualizados. Todavia, é necessário ter precaução: o facto de em escavações ou prospecções terem sido recolhidos "materiais muçulmanos" não implica a existência de uma ocupação do local em época muçulmana. Em alguns casos (para esta região como para a zona de Elvas) conhecemos algumas informações porque o registo nos foi deixado por um arqueólogo particularmente atento a estas realidades, Abel Viana.

${ }^{(21)}$ Trata-se de um termo de carácter polissémico excessivamente abrangente para as realidades arqueológicas que vão sendo identificadas, seja pela ausência de uma definição clara a partir das fontes coevas, seja pela diversidade personalizada ao gosto do encomendante dos elementos construtivos existentes em cada sítio. Esta é uma discussão de âmbito muito vasto, que por ser estranha a este tema também ficará para outra ocasião. Veja-se Perez Losada 1987 ou Gorges 1979, com casos práticos em Carneiro 2004.

${ }^{(22)}$ Chavarría Arnau 2004a, com numerosos exemplos. Na Lusitânia o fenómeno é mal conhecido, mas poderemos ter um exemplo em Monte do Meio, Beja (Viana 1959: 36-43). Inversamente, em certos casos, como em Torre Águila, o antigo lagar continua em funcionamento até ao século VII, não havendo qualquer transferência do complexo produtivo. 


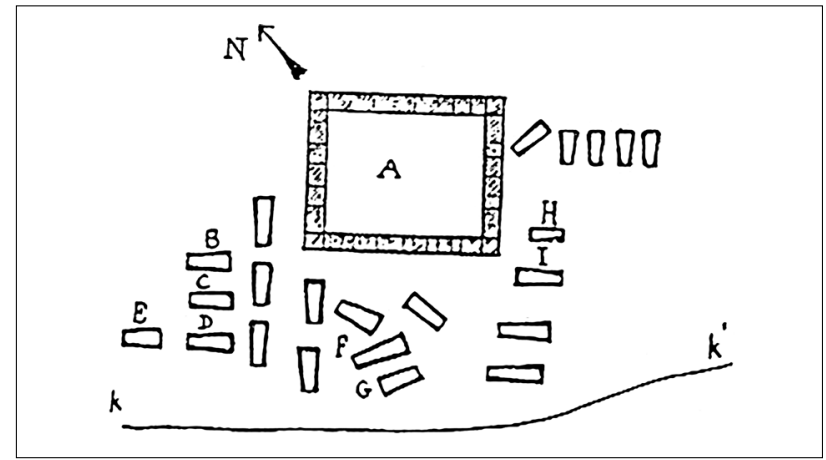

A Figura 2. Herdade da Terrugem (Viana, 1950: fig. 19).

"três moedas de bronze, romanas, perfuradas, mostrando assim, terem sido usadas como adornos ou como amuletos ${ }^{23 "}$ (fig. 2). Desta necrópole provém uma colher com a inscrição AELIAS. VIVASIN e com o característico crismon cristão.

Também em Silveirona (Estremoz) se documentou uma ampla reutilização de materiais romanos na necrópole cristã, tendo inclusivamente o que parece um edifício de tipo mausoléu sido construído nas estruturas da villa romana anteriormente ocupada (fig. 3). Nos casos referenciados, parece tratarse de um fenómeno cronologicamente muito preciso e delimitado no tempo, em torno aos séculos IV (nos momentos finais) e $V$, sendo abandonado à medida que se vão construindo edifícios de culto que irão assumir, neste processo, um novo efeito polarizador e congregador. No en- tanto, se olharmos para a escala peninsular, observamos uma assinalável diversidade em todo este processo, com a existência de extensas necrópoles, de sepulturas agrupadas, de sepulturas isoladas ou ainda com apenas um sarcófago ocupando uma posição central.

Neste processo temos portanto uma alteração no domínio das mentalidades e da, digamos, vivencialidade do espaço: comunidades que abandonaram a ocupação das estruturas da villa romana, mas que a utilizam como local de deposição funerária. Seria interessante avaliar se nestes sítios a utilização das estruturas arquitectónicas ainda subsistentes seria reformulada como local de culto, com a necrópole nas suas imediações, ou se se mantinha a, digamos, dimensão pagã do local. De qualquer forma, temos um processo dicotómico: se por um lado as estruturas áulicas são reconvertidas de espaço de vivência em ambiente funerário, evidenciando uma ruptura nos mecanismos psicológicos de ocupação do território, por outro existe sem dúvida uma relevância (mesmo que seja apenas no plano simbólico) que leva a que a comunidade se deseje manter vinculada aquele espaço (mesmo que o perfil de ocupação seja agora radicalmente distinto), não se afastando para novos lugares ${ }^{24}$.

Já a reconversão de elementos da pars urbana em templo cristão surgenos surpreendentemente mal documentada, quer nos contextos, quer nos ritmos em que terá ocorrido ${ }^{25}$. Todavia, nos poucos casos referenciados parece haver dois momentos: até ao século $V$, a construção ocorre reformulan-

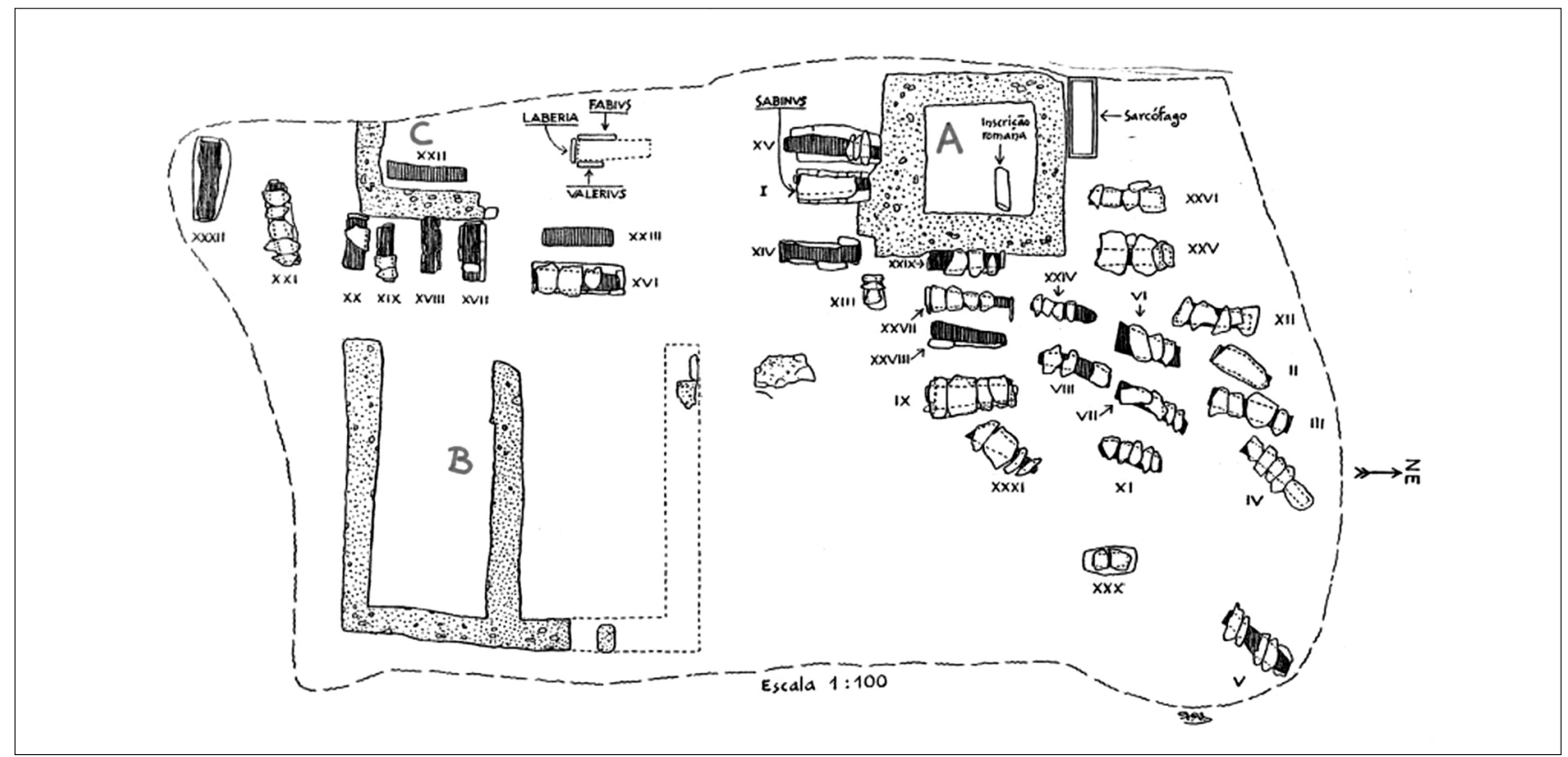

A Figura 3. Herdade da Silveirona (Estremoz): desenho de Francisco Valença (reproduzido em Cunha, 2004: 160).

(23) Deus, Louro e Viana 1951: 572

$\left.{ }^{24}\right)$ Este ponto é particularmente interessante se tivermos em consideração um outro fenómeno, pois em certos casos existem necrópoles que possuem uma larguíssima diacronia de utilização (embora não necessariamente in continuum), ou seja, quer na proximidade ao espaço de vida, quer na perpetuação do espaço sepulcral, encontramos para este período tardio um conjunto de feixes de continuidade com o mundo clássico (Carneiro 2002, quadro p. 146-147; Frade e Caetano 1993).

${ }^{25}$ ) Ver o artigo fundamental de Lopez Quiroga e Rodriguez Martín (2000-2001), com ampla bibliografia. 
do um templo pagão pré-existente no edifício (exemplo paradigmático em outra área regional, na villa de Fortunatus em Huesca, mas na Lusitânia existem casos em Torre Águila, Badajoz, Montinho das Laranjeiras, Alcoutim, S. Cucufate, Vidigueira ou Monte da Cegonha em Beja); em momento posterior, constróise de raiz, nas imediações do edifício de residência (Torre de Palma, La Cocosa e La Sevillana, em Badajoz). Um caso particularmente interessante parece ter-se registado em Milreu: no século IV ou V dá-se a transformação da cella do antigo templo pagão (interpretado como um ninfeu dedicado às divindades aquáticas) em local de culto cristão, aparentemente respeitando o ambiente arquitectónico do edifício $^{26}$. Durante o século VI ou VII a construção de um baptistério dota o complexo de uma abrangência simbólica mais ampla. Esta evolução interna deve de algum modo alertarnos para as diferentes velocidades destes fenómenos de progressiva reformulação dos espaços sagrados.

Também do ponto de vista da implantação existem algumas variantes. Em primeira fase, esta "intrusão» do templo cristão parece ser endógena, a partir do espaço edificado pré-existente. No momento seguinte, desloca-se para um edifício marginal, seja situado em ponto periférico da estrutura áulica (Torre Águila, La Cocosa) ou manifestando-se no complexo termal (situação muito frequente, por exemplo, na península itálica ${ }^{27}$ ou na Catalunha, e menos conhecida na Lusitânia).

Em alguns casos, a construção de um edifício basilical dota estes lugares de grande relevância regional, funcionado como âncora que concede estabilidade e persistência a estes lugares que assim permanecem como pólos locais ou regionais durante os séculos V a VIII. Em Torre de Palma, o local de culto recebe pelo menos três grandes obras de ampliação, até ser dotado de um baptistério e de um possível martyrium por trás de uma das absides. Em La Cocosa (Badajoz) no século VI terá sido construído um possível martyrium, ocupando um edifício de planta tetralobulada com uma cripta, e certamente que o local, também dotado de baptistério, se transformou em importante centro de reunião, possivelmente de âmbito local (fig. 4). Outro sítio que provavelmente beneficiou de uma certa preponderância foi Monte da Cegonha, com uma basílica de três naves em torno da qual se foi estruturando uma necrópole.

Como será natural estas alterações seriam sentidas em outros campos. A actividade religiosa supõe a presença de um presbitero, que forçosamente teria de habitar próximo do local de culto, construindo assim novas relações de sociabilidade. Estes edifícios anexos poderão portanto vir a ser identificados, permitindo construir novas leituras do ponto de vista espacial. Igrejas, residências anexas e baptistérios serão doravante elementos constituintes da nova arquitectura do território.

No campo das reconversões funcionais e arquitectónicas, portanto, temos várias direcções possiveis, com dinâmicas evolutivas específicas. É um facto que a situação poderia ser avaliada de forma mais rigorosa se tivéssemos melhor conhecimento dos programas decorativos existentes no interior das construções. Mas nesse campo os dados são ainda mais escassos.

Durante o século IV, a generalidade das villae assiste a grandes projectos de renovação arquitectónica, datando desta época a construção dos mais luxuosos equipamentos e grandes ampliações do espaço construído. Aproveitando um contexto político favorável (nomeadamente a presença de um Imperador hispânico, Teodósio), várias villae lusitanas recebem amplos benefícios, como Torre de Palma ou La Cocosa, que chegará a atingir mais de dez hectares construídos. Curiosamente, os programas decorativos são ainda de raiz clássica, como as figurações do cortejo báquico ou das musas em Torre de Palma, ou a cena de Ulisses em Santa Vitória do Ameixial. Mais longe, os patronos da villa de La Olmeda retratam-se em medalhões, junto a uma cena de Ulisses na corte do Rei Licomedes. Annius Bonus, em Méri$\mathrm{da}$, veste uma toga enquanto se retrata com os atributos de Dioniso. Ampliando a leitura e olhando para a Península, os exemplos multiplicam-se.

Por incrivel que possa parecer ao observador, estes proprietários de cunho clássico poderiam ser já cristãos convictos. No momento em que se constrói o ninfeu da Quinta das Longas, numa divisão mais recatada coloca-se um discreto crismon no pavimento de mosaico ${ }^{28}$ (fig. 5). 0 caso mais exemplar é o do proprietário da villa de Carranque (Toledo), Materno, provavelmente o mesmo que foi um homem de confiança directa do Imperador Teodósio, um acérrimo cristão (provavelmente por influência de sua esposa) mas cujas obras de arte e programa decorativo empregue na villa são integralmente de indiscutivel cunho pagão.

Esta ambiguidade só aos nossos olhos pode parecer paradoxal, sendo perfeitamente natural para uma época de

${ }^{(26)}$ Como é óbvio, o tema da água prestava-se particularmente bem à reconversão do culto religioso, quer em termos simbólicos, quer nas soluções práticas do ponto de vista estrutural e decorativo (Hauschild 1984-88). É no entanto fundamental ler a situação com alguma precaução, pois deste sitio provêm alguns retratos imperiais em mármore, sendo que está comprovada a associação entre o culto imperial e as águas (com paradigma bem evidente no templo de Évora, e de resto basta pensar na etimologia do pontifex), para além de conferir à vivência da villa um ambiente formal muito conservador (Cardim Ribeiro 1982-83: 186 e seguintes). Finalmente, para tornar o quadro mais complexo, de relembrar que neste sítio arqueológico foi ainda encontrada uma cabeça em terracota interpretada como uma figuração da deusa Ísis...

(27) Talvez a situação mais emblemática seja a de Catania, onde das seis termas públicas, quatro foram reconvertidas em lugares de culto cristão (Reis 2004: 45).

${ }^{(28)}$ Oliveira, Cristina; Carvalho, António e Almeida, Maria José de [no prelo]. Agradeço a António Carvalho a cedência das imagens. 
A Figura 4. Planta da villa de La Cocosa, Badajoz (reproduzido em Lopez Quiroga e Rodriguez Martín, 2000-2001, fig. 3).

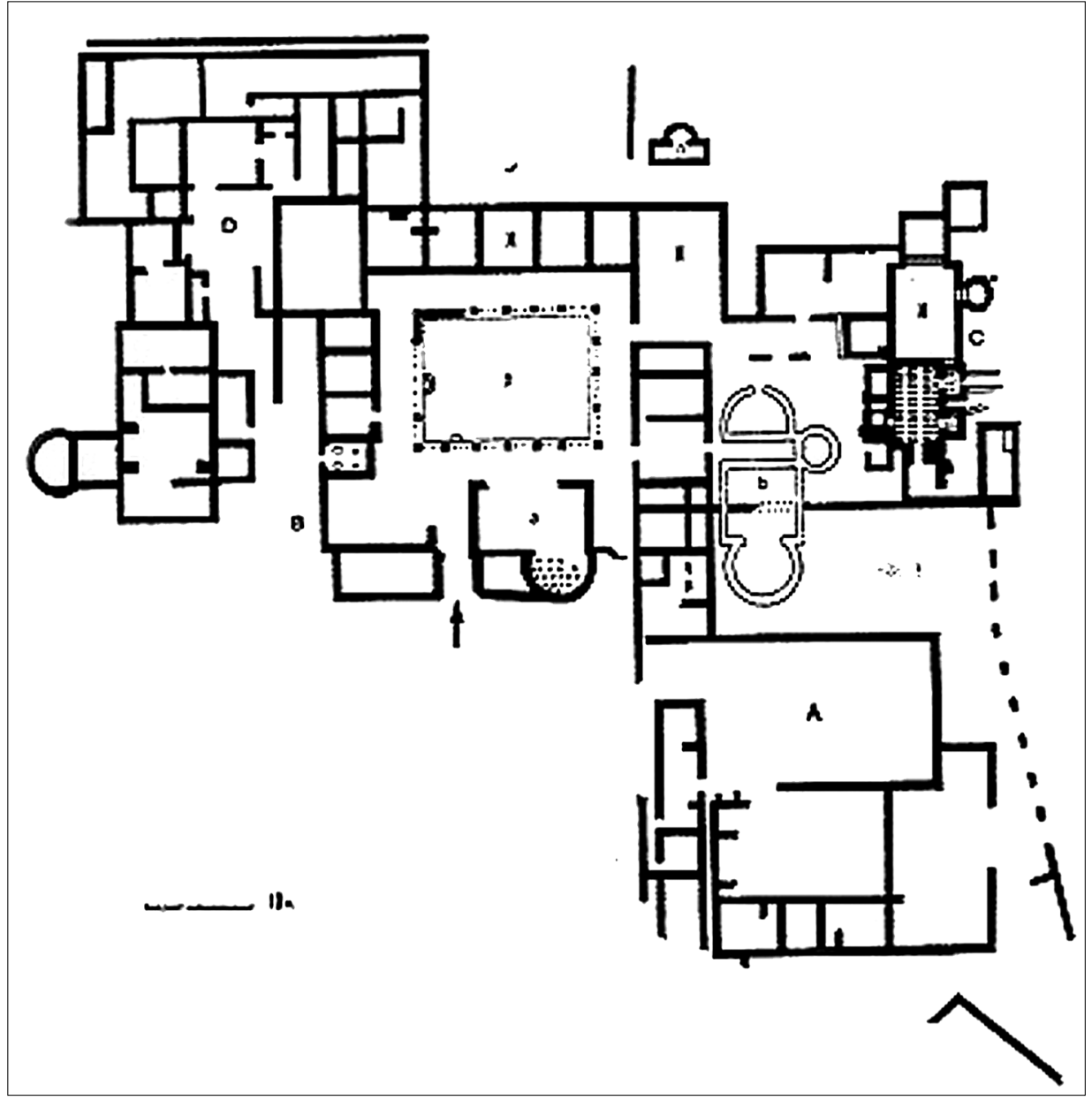

viragem, na qual os cânones e ortodoxias não estão ainda suficientemente cristalizados para impedirem uma permeabilidade que terá sido muito efectiva ${ }^{29}$. Há portanto aqui que colocar a análise em dois planos: as concepções e representações dos ciclos mitológicos, entendidos enquanto elemento estruturante de uma mundividência cultural e de uma vivencialidade quotidiana que se mantém, e o sentir religioso, a adesão a um novo universo de práticas e de sentimentos, que não é conflituante com o elemento anterior. A mitologia clássica continua a servir como aferidor de elevada erudição, como elemento materialmente utilizável de uma ostentação ligada ao otium e à fruição estética, e este quadro, com certas cambiantes, mantém-se muito para além do fim do Império ${ }^{30}$, devidamente matizado, é certo, com fenómenos de contra-cultura sobre os quais já nos iremos deter e onde podemos antever uma adesão mais radical ao novo panorama religioso. De resto, podemos encontrar no sentimento religioso baixo-imperial uma evolução no sentido do realce espiritual, na preocupação com uma maior reflexão e circunspecção, nas especulações sobre o destino post mortem, ou seja, um conjunto de factores de evolução que vão progressivamente dotando os quadros mitológicos clássicos de um sentimento religioso mais profundo e individualista ${ }^{31}$.

Nestes casos, como em outros sítios na Península, a construção de basílicas privadas abertas à comunidade envolvente expressa os últimos indícios de "un exponente singular del ervegetismo llevado a cabo por las elites rurales a imitación de lo que se estaba produciendo simultáneamente en los ambientes urbanos com la construcción de los grupos episcopales ${ }^{32 " . ~ E s t a s ~ u ́ l t i m a s ~ m a n i f e s t a c ̧ o ̃ e s ~ d e ~ e r v e g e-~}$ tismo -ou, mais rigorosamente, de uma munificiência privada- constituem os últimos estertores de uma clivagem social que era marcada pelo elitismo cultural, pela diferenciação de uma aristocracia caracterizada sobretudo pelo

(29) Sottomayor 1990

(30) Basta pensar na corte de Carlos Magno, claramente imbuída de um conjunto de arquétipos de representação de cariz clássico.

(11) Neste amplo campo temos as influências neo-platónicas de tão grande impacto no cristianismo primitivo ou, em outro plano, a passagem de uma representação naturalista no domínio da arte para uma estética mais profunda fortemente impregnada de conceitos simbólicos e de uma desconstrução do domínio visual imediato. Sobre os aspectos filosóficos, ver Moreschini 1989.

(32) Lopez Quiroga e Rodriguez Martín 2000-2001: 143 


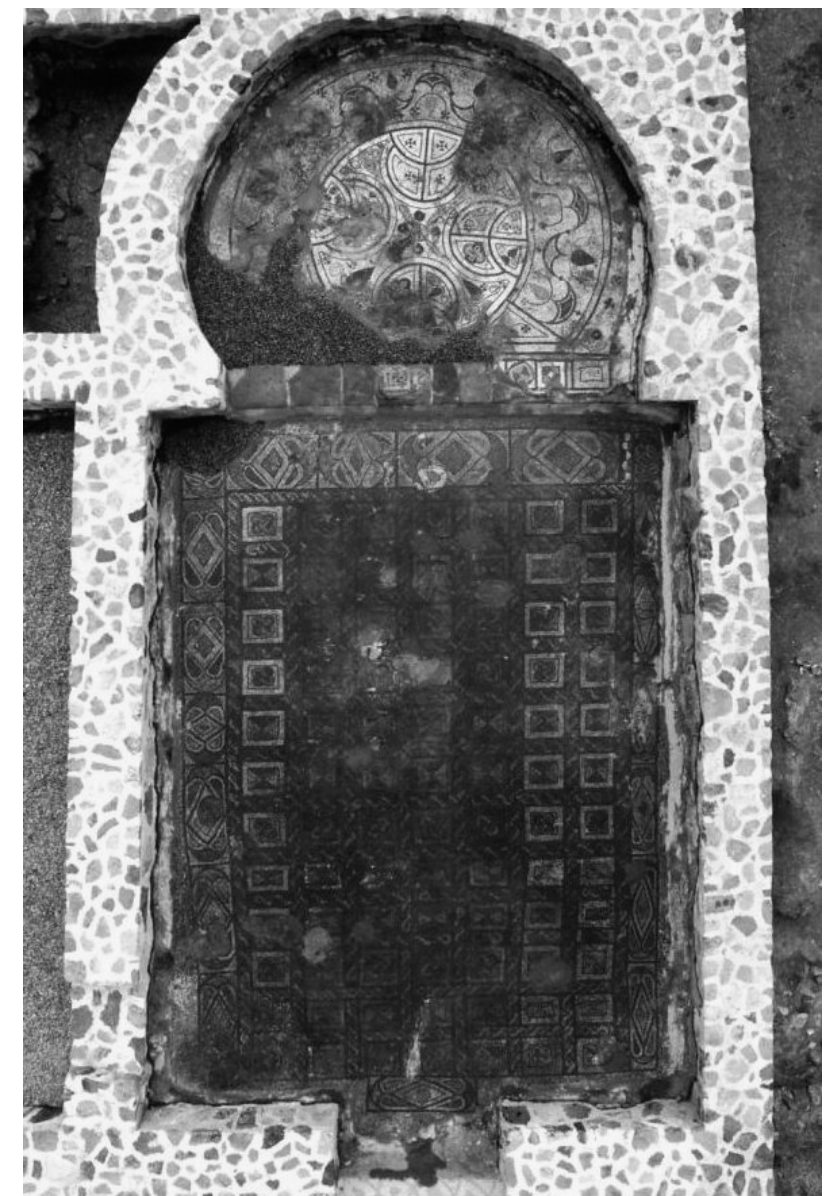

ideal do otium que a distinguia das massas laborantes. 0 grande trunfo do cristianismo, a sua capacidade de entrada nesta sociedade, é precisamente no esbatimento desta barreira, pois "A la fin du Vle siècle, cette limite disparaît: la culture du chrétien ordinaire devient pour la première fois identique à celle des évêques et des dirigeants" ${ }^{13}$ enquanto 0 trabalho ganha uma apreciação dignificante. É no entanto interessante notar que nestes últimos fenómenos de ervegetismo -uma tradição tão caracteristicamente imperial- encontramos já os primeiros traços de uma atitude de, digamos (e passe o sempre indesejável anacronismo), proto-feudalismo, pois a construção das primeiras basilicas em ambiente rural ou a oferta de latifúndios é feita por grandes proprietários (geralmente figuras ainda ligadas às magistraturas urbanas, mas já em processo de transferência para o papel de possessores rurais) que procuram criar pontos sólidos de convergência das comunidades próximas, funcionando o local de culto também como elemento de substituição face à autoridade política central em desagregação.

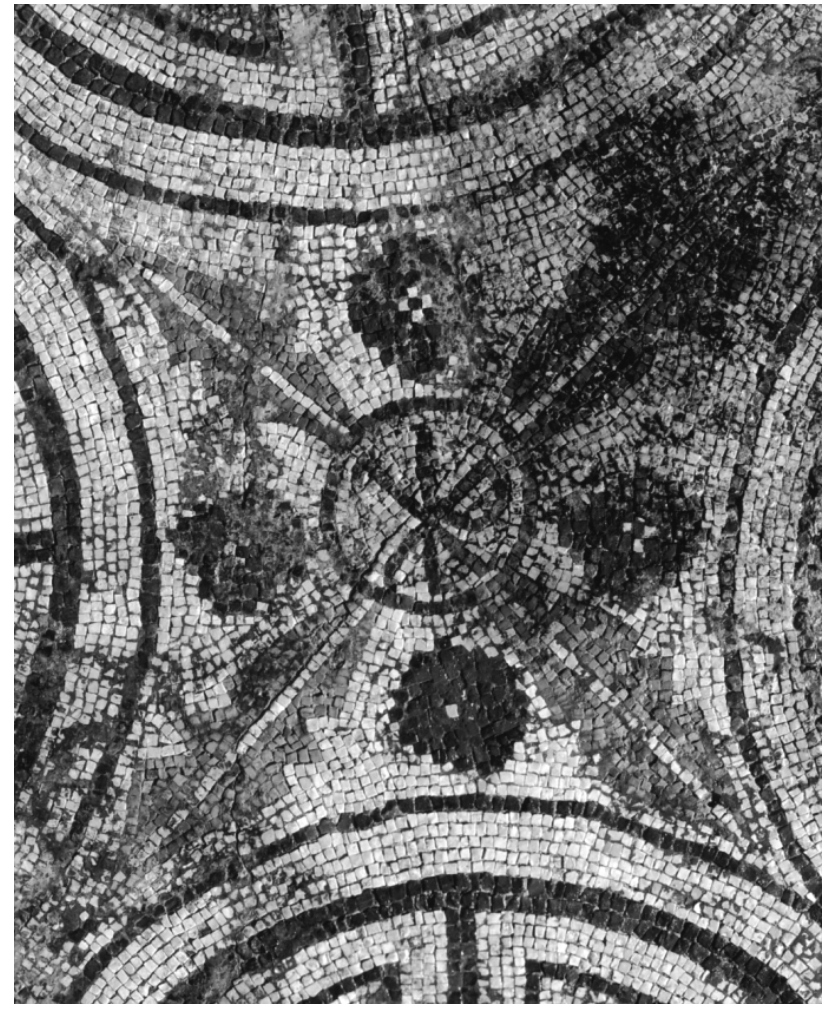

A Figura 5a e 5b. Villa romana da Quinta das Longas: divisão onde foi encontrado o crismon e seu pormenor. Fotos Danilo Pavone/PEVLONG, gentilmente cedidas por António Carvalho

Mais do que questões da ordem administrativa ou religiosa, temos aqui um processo de afirmação pessoal de uma elite que vai procurando vincular os rustici à sua própria figura, criando uma polarização em torno de um local de reunião da comunidade.

Neste processo podemos entrever a fragmentação do conceito clássico de villa com a progressiva implementação de um proto-aglomerado estruturado em torno de um símbolo de autoridade religiosa e não política. Esta transferência da villa para a "vila» medieval é infelizmente ainda mal conhecida no nosso país ${ }^{34}$, mas parece constituir a paradoxal solução de, por um lado, permitir a sobrevivência material destes espaços em meio rural, mas por outro levar à sua extinção do ponto de vista do paradigma conceptual que o termo villa implica ${ }^{35}$ através de uma radical reformulação do conjunto de conteúdos que originou o nascimento destas estruturas.

Como é evidente, estes mecanismos de transformação na vivência dos lugares trouxeram também outras mudanças,

(33) Brown 1995: 170.0 cristianismo vai criar outras barreiras, mais transversais do ponto de vista social, baseadas em distinções moralistas entre os homens virtuosos, modelos de emulação pela sua piedosa actuação, e os pagãos ou pecadores.

${ }^{(34)}$ As leituras que propunham uma grande linearidade nesta evolução já foram suficientemente contraditadas: Alarcão 1998, que introduz um elemento importante de discussão, o papel que as circunscrições paroquiais poderão ter tido ao nível local e regional, esbatendo a evolução directa. Mais uma vez, falta-nos um conhecimento exaustivo da documentação medieval, não esquecendo as especificidades que a invasão muçulmana originou no nosso território; aliás, sobre este campo, consultese Boissellier (1999).

(35) Lopez Quiroga e Rodriguez Martín 2000-2001: 149. 
mais profundas e dificeis de perceber, na ordem e estrutura social. Porque a religião cristã supõe uma libertação do estatuto de escravo, os vínculos entre as classes têm forçosamente de se alterar, nem que seja meramente no plano jurídico. Todavia, a fragmentação do habitat e a sua ruralização, tantas vezes encaradas como mais um sintoma de decadência, poderão ser reflexo desta estrutural alteração.

Infelizmente, para um melhor conhecimento destas dinâmicas falta-nos informação referente a dois campos essenciais.

Por um lado, o domínio das transformações arquitectónicas, ou seja, a introdução de novas técnicas e modelos de construção. 0 tradicional agrupamento dos grupos arquitectónicos mediante características formais e estilisticas tem sido alvo de sucessivas revisões ${ }^{36}$ procurando definir, com 0 suporte do registo estratigráfico, ritmos e momentos de introdução dos diversos cronotipos caracterizadores das novas formas de construir: colunas, pilares, arcos, abóbadas, lintéis e coberturas, mas também a utilização e combinação dos diversos materiais e tipos de alvenaria. No entanto, para o nosso território, o cuidado registo e descrição arquitectónica (e sua publicação gráfica) foi por muito tempo negligenciado, tendo sido introduzido apenas nas escavações mais rigorosas (não necessariamente as mais recentes). Geralmente partese de um préconceito (no sentido etimológico do termo) de que as construções vão decaindo em qualidade e rigor com o decorrer do tempo, sendo frequentes os qualificativos de "grosseiro" ou "rústico" para os sistemas construtivos do século IV em diante, sem que deles sejam feitas descrições pormenorizadas. Este vício de leitura é ainda agravado pelo facto de esquecer que, em plena época imperial, viviam nas villae numerosos trabalhadores rurais que não tinham acesso aos luxuosos compartimentos com sistemas de aquecimento e pavimentos de mosaico, mas estavam confinados a modestas habitações com pisos em terra batida e coberturas em materiais pereciveis, com os consequentes saberes e operacionalidade técnica que vão transportando consigo ao longo das gerações.

E no entanto, os contextos tardios oferecem-nos soluções de grande originalidade e complexidade formal, como os espaços poligonais, de dupla ábside, as aulae quadrilobuladas ou ainda as diversas plantas basilicais, sem esquecer os elementos portantes específicos, como as variadas soluções de arco, dos quais o de ferradura é porventura o mais conhecido. Um domínio dos morfotipos arquitectónicos e das soluções técnicas que não pode ser unicamente atribuído à chegada de artífices ou influências externas, geralmente conotadas com o florouit bizantino ${ }^{37}$.

0 grande campo de trabalho que tem sido esquecido é, no entanto, o imenso e complexo mundo da cerâmica. Extintos os cómodos fósseis directores do mundo imperial, o registo artefactual do século $\mathrm{V}$ em diante apresenta um panorama mais difuso, com o retrocesso das técnicas fazendo ressurgir protótipos formais que fazem curiosamente (ou talvez não...) lembrar as produções da Idade do Ferro indígena. Materiais de aparência grosseira, que têm afastado o olhar dos investigadores. E o mesmo se verifica nas peças de importação que ainda chegam a este território, pois o estudo da terra sigillata de proveniências africanas e orientais que estão presentes nos contextos tardios ainda está em grande medida por fazer.

\subsection{A mudança arquitectónica como reflexo de um novo paradigma}

No quotidiano, o despojamento torna-se evidente. Dois exemplos servem para ilustrar a tendência: Sidónio Apolinário ${ }^{38}$ refere a história de Máximo, antigo responsável da administração provincial, que se retirara para a sua villa, onde se alimentava de modo frugal, usava uma longa túnica e deixara crescer a barba. No Capítulo III do Liber Vitas sanctorum patrum Emeritensium narra-se a trágica história do Abade Nancto, que recebeu uma propriedade próximo de Mérida e foi assassinado pelos habitantes locais, que se recusaram a servir um dominus de recursos tão pobres ${ }^{39}$. Este episódio chama a atenção para outro fenómeno frequente: a doação de propriedades com os seus habitantes a congregações de monges. É o caso do episódio de Paulino e Terasia (Aquitânia), que doaram as suas propriedades a uma comunidade de fiéis, ou de Melania a Jovem, que libertou 8000 escravos e utilizou a sua fortuna pessoal numa peregrinação à Terra Santa. Mesmo tendo em consideração que a função moralista destes episódios é evidente, impedindo a percepção exacta da veracidade do seu fundo histórico, percebe-se que de algum modo reflectem episódios que efectivamente ocorreram: a liquidação de bens monetários e fundiários e a sua distribuição por desfavorecidos ou doação à Igreja ${ }^{40}$; actividades caritativas várias; libertação de escravos; peregrinações à Terra Santa ou périplos por outros locais sagrados.

(36) Ver por exemplo todo o balanço historiográfico contido em Utrero Agudo (2006: 25-45).

${ }^{(37)}$ Que de resto no nosso pais está mal documentado e poderá ter tido impactos restritos e específicos.

${ }^{(38)}$ Epistola, IV, 24, 3-4. Exemplo que terá causado uma impressão ainda mais marcante no autor, pois este estava claramente vinculado aos paradigmas vivenciais clássicos.

(39) Este episódio é particularmente interessante por nos relatar uma situação de tipo colonato, pois a propriedade é transferida juntamente com os seus trabalhadores, que não são escravos, mas homens livres vinculados à terra (Chavarria Arnau 2004b). Demonstra também a preocupação política de Leovigildo em proceder a uma conciliação religiosa, pois Nancto era aparentemente ariano (Velázquez 2005: 185-186).

$\left({ }^{40}\right)$ Exemplo paradigmático na doação à igreja de Augusta Emerita do património de um casal cuja mulher fora salva pela intervenção médica do bispo Paulo, narrada nas Vitas Sanctorum Patrum emeritensium (IV-2). 
Para a Lusitânia estes fenómenos não são ainda bem conhecidos, mas deverão ser tidos em conta na análise, e poderão explicar duas tendências: a construção de edificios religiosos, por vezes em plenas estruturas pagãs, mas também a paulatina passagem de um ambiente áulico, de luxuria privata, para a introspecção reflectindo uma vivência despojada e humilde. Sublinhar este aspecto é importante, pois na prática estamos apenas perante uma alteração no paradigma de vivência quotidiana, embora as explicações historiográficas tradicionais tendam a ver nestes processos de despojamento a "perda das técnicas", os "retrocessos tecnológicos" ou, em casos em que prevalece uma leitura étnica, a substituição do fundo indígena por populações ditas "bárbaras". 0 que temos, então, é um processo de afirmação de novos valores culturais, ou seja, onde em tempos anteriores tínhamos a ostentação, agora temos a austeridade.

Será interessante tentar perceber se estes processos são originados a partir do interior dos núcleos de habitantes ou se processam depois de transferências de propriedade e sua ocupação por novos donos (novos proprietários, o que não significa novas gentes ou invasores). Rastrear os ritmos e formas desta mudança de paradigma, por vezes interpretada arqueologicamente como reflexo das perturbações e insegurança causadas pelas invasões bárbaras, mas que afinal poderá reflectir tão somente uma mudança nos esquemas organizativos da vivência quotidiana e das mentalidades, será por certo um dos desafios para a investigação arqueológica, por vezes ainda demasiado vinculada à explicação historiográfica tradicional.

\subsection{As construções religiosas e as novas vivências: eremitérios e mosteiros}

Uma das tendências mais interessantes, mas mais imperfeitamente conhecida em toda esta área regional, tem a ver com a "fuga do mundo".

As correntes ascéticas e místicas que, por influência oriental ${ }^{41}$, chegam à Península (infelizmente em momento ainda indeterminado) levam à fixação de indivíduos isolados ou de pequenas comunidades em grutas naturais ou em zonas isoladas de montanha (os verdadeiros «desertos» dos místicos), ocupados pelos eremitas. Em alguns casos, estas práticas mais radicais mesclamse com algumas correntes heréticas que propunham o despojamento e o abandono das realidades materiais.

Rastrear estas práticas é tarefa complexa, desde logo pelas suas características intrínsecas: ocupação de pontos de difícil acesso e ausência de uma cultura material identificativa, devido ao desprendimento e rejeição dos bens físi- cos. Mesmo assim, existem algumas indicações. Em particular, registamse fenómenos de ocupação em montes e lugares sagrados, como a Serra d'Ossa ou a Serra de São Mamede.

Já as práticas comunitárias, ou os costumes relacionadas com uma vivência distanciada das realidades mundanas, e dedicada ao ascetismo, à meditação ou a uma vocação cenobítica, são mais bem conhecidas na Lusitânia. Quer do ponto de vista arqueológico, quer literário, estando neste último caso o exemplo do Abade Nancto, que se retirou para o campo com alguns irmãos construindo um uilissimum habitaculum $^{42}$.

Esta situação obedece a várias preocupações, mas parece existir uma motivação central, pois a construção de pequenas igrejas afastadas de núcleos de povoamento prende-se com a necessidade de conquistar terreno aos pagãos, ou seja, de fundar pequenos templos em territórios periféricos. São igrejas afastadas de villae ou de núcleos urbanos, como a de Valdecedabar (Olivenza) ou a de San Pedro de Mérida, e de certa forma já correspondem às exortações martinianas, pois o De Correctione Rusticorum recomenda aos habitantes dos campos que frequentem as ecclesiae e os loca sanctorum, entendendo a evangelização no ambiente rural como a grande tarefa que o Cristianismo deve agora, nesta nova fase, realizar. Esta intenção indica-nos que o culto pagão continuava a congregar os sentimentos das populações. Portanto, torna-se vital a fundação de pontos a partir dos quais a mensagem cristã pode ser emitida em permanência para as comunidades envolventes e onde os monges, pelo seu exemplo de trabalho e dedicação, podem captar novos fiéis. Nesta segunda fase, portanto, o campo de batalha contra o paganismo desloca-se dos meios urbanos, onde o estabelecimento da religião já encontra consolidado, para os agri rustici, onde as práticas pagãs conservam assinalável vitalidade.

Todavia, a obra de Martinho também adverte para os sinais contrários, sintoma de que eles eram praticados: práticas supersticiosas que eram conduzidas por cristãos, incluindo membros do clero, e que deviam ser terminantemente abandonadas. Interessante é o facto de através dos seus escritos podermos percepcionar o modo como toda a paisagem (embora, é certo, em palco geográfico diferenciado, a província da Gallaecia) era polvilhada de conteúdos simbólicos, lugares fantásticos e impregnados de superstitiones (no sentido clássico do termo) que apelavam a comportamentos menos condizentes com as práticas cristãs. Neste moralismo percebemos que a domesticação da paisagem através da criação de pontos de referência é uma das preocupações essenciais nestes momentos iniciais, procu-

${ }^{(41)}$ Embora na Península não tenhamos conhecimento de variantes mais radicais como os estilitas, que vivem em cima de uma coluna; mesmo os emparedados são referências muito posteriores.

(42) Velázquez 2005: 185. 
rando esconjurar os numina, os genii e todas as tentações que provocavam os fiéis ${ }^{43}$.

Paralelamente procuramse criar corredores de circulação que permitam a livre propagação da mensagem através de um fácil trânsito das pessoas que a trazem. Desta forma, constroem-se pequenos conjuntos monásticos em zonas próximas de grandes eixos de comunicação, funcionando possivelmente como pontos de apoio para peregrinos. Junto à capital provincial, por exemplo, há uma densa concentração de pequenas unidades que poderão ter assumido estas funções, relacionadas também com o crescente culto a Santa Eulália que Mérida começava a albergar. Infelizmente para o território actualmente português não temos evidências destes edifícios, mas em alguns casos, como Torre de Palma, conseguimos perceber a relação com a via existente nas proximidades.

\subsection{Outros campos de informação}

\subsubsection{A epigrafia}

Na Península lbérica, as inscrições cristãs começam a surgir durante o século IV, parecendo ser possível cartografar um movimento de progressão para o Atlântico, começando na fachada catalã, espalhando-se pelas Baleares e Levante até atingir a Bética ${ }^{44}$. Na Lusitânia as primeiras manifestações surgem-nos todas baseadas em Mérida, a partir da segunda metade da centúria, estando a primeira datada de 381.

Neste momento, já em torno da basílica de Santa Eulália existia uma grande necrópole cristã, onde estaria, em grande mausoléu, o martyrium, que nos surge descrito por Prudêncio, no século IV ${ }^{45}$. A epigrafia da capital da Diocesis Hispaniarum demonstra, para os séculos seguintes, a proliferação de locais de culto que sustentam a dinâmica da vida urbana que, em outros campos, já se encontrava em progressiva ruralização com a decadência das actividades políticas. Essa vitalidade era em grande parte alimentada pelo culto a Santa Eulália, que concentra grande percentagem das epígrafes encontradas ${ }^{46}$, e que certamente levaria à extensão para os territórios envolventes de infra-estruturas de apoio aos peregrinos que demandavam a cidade.

\subsubsection{Os elementos escultóricos e arquitectónicos}

Entre as construções que vão invadindo os campos, temos um conjunto variado de tipologias, com eremitérios, mostei- ros, ermidas, pequenas capelas, basílicas ou igrejas. É certo que falta um profundo conhecimento do território nesta área geográfica para que possamos dispor de um recenseamento das estruturas desta época. Mas é também necessário ter em consideração que, na sua variedade arquitectónica e diversidade estrutural, estes locais de culto tinham de albergar um conjunto de elementos móveis e arquitectónicos que permitissem o correcto cumprimento das suas funções.

Neste campo específico o desconhecimento é tremendo. As cartografias existentes dos elementos escultóricos com decoração paleocristã já necessitam de actualização ${ }^{47}$ em face de novos elementos que têm sido identificados. E a utilidade deste campo de análise é evidente, pois estes materiais arquitectónicos dão-nos dois tipos de informação.

Por um lado teríamos um ainda considerável número de pequenos templos dispersos pelo território, visto que muitos pés de altar, frisos, ábacos e fragmentos de cancela (entre outros elementos) pertencem a basílicas, ermidas ou pequenos templos que se encontram em lugares rurais, por vezes mesmo em zonas bastante marginais.

Por outro lado, a sua presença fornece-nos indirectamente informação sobre a actividade das pedreiras e dos canteiros e escultores muito para lá do fim do Império. Apesar das diferenças de extracção e talhe da pedra e das novas estilísticas em relação ao período imperial, o número (crescentemente progressivo) destes exemplares, na sua maior parte obtidos em mármore do complexo Estremoz/Vila Viçosa, permite-nos perceber que o horizonte temporal de abandono destas actividades fundamentais do ponto de vista económico será certamente mais tardio do que geralmente se supõe.

\section{NOTAS DE FECHO}

Entre o panorama catastrofista e as novas leituras trazidas mais recentemente pela investigação arqueológica, os dados relativos à província da Lusitânia apresentamse ainda demasiado escassos e fragmentados para que deles se possam extrair análises mais fiáveis. Seja qual for o ângulo de abordagem, ou o campo de trabalho escolhido, é notória a ausência de feixes de informação suficientemente estáveis para a percepção dos processos de permanência ou transformação. Por exemplo, não há uma única sucessão estratigráfica publicada que permita sequenciar este processo de forma mais fiável.

(43) Embora seja detectável alguma tensão entre as autoridades episcopais e estes pequenos núcleos, por vezes em espaços periféricos e com grande autonomia, que decorre de uma disputa pelos recursos e bens patrimoniais das propriedades onde o templo se implanta e na sua envolvência. Sobre este assunto ver Buenacasa Perez 1997

(44) Em particular Vives (1947).

(45) Peristefanon, III, IV e XI. É de notar que muitas das descrições ali feitas pelo autor, quer da estrutura arquitectónica do edificio, quer do martírio de Eulália, parecem ser a reprodução de fórmulas literárias e portanto não deverão ser lidos à letra. Após o saque de 429 o local vai ganhando progressivamente fiéis, e as obras de ampliação empreendidas entre 530 e 560 comprovam a importância do edifício.

$\left({ }^{46}\right)$ "Las dos terceras partes de las lápidas, de las que conocemos su procedência, se hallaron en lo que podemos definir como el área funerária cristiana de Sta. Eulália" (Ramirez Sadaba e Mateos Cruz 2000: 273

${ }^{(47)}$ Em especial Almeida e Fresco de Almeida 1987. 
Todavia, algumas linhas de força emergem. Uma entrada do Cristianismo em meio urbano relativamente rápida e estável, constituindo-se como principal elemento de coesão social durante as perturbações do século IV e, em especial, ao longo do século $V$, talvez o momento em que as informações são mais difusas e frágeis. Será certo que a intensificação dos concílios e o acréscimo das referências documentais ao longo dos séculos VI e VII mostram que a organização do culto resistiu aos colapsos políticos, reforçandose pela progressiva hierarquização das suas estruturas.

Será durante este momento que a paisagem rural sofre uma nítida evolução, com a criação de marcos na paisagem que irão organizar as comunidades de rustici. Se até aí a presença cristã tinha penetrado no interior das estruturas pagãs, associadas sobretudo às estruturas quotidianas do fundo civilizacional anterior, agora assistimos a um assumido movimento de colonização da paisagem procurando integrar ou mesmo combater as marcas do paganismo dominante. As dificuldades e a lentidão deste processo deixaram traços na paisagem física e na memória dos lugares, sendo perceptível que mesmo no Alentejo de hoje ficaram marcas de tradições milenares nos usos e costumes.

Este é o panorama geral, infelizmente ainda pouco preciso. Para a investigação, o desafio passa por criar sequências mais finas de modo a perceber a verdadeira extensão dos ritmos de mudança, visto que para a esmagadora maioria dos sítios arqueológicos as cronologias são aproximadas a intervalos de duzentos ou mais anos, o que objectivamente não serve de grande utilidade.

As perspectivas de inspiração estruturalista têm utilizado uma imagem para ilustrar este momento histórico: a do oceano, onde sob a superfície ondulante e encapelada, teríamos nas águas profundas uma grande estabilidade, uma permanência tranquila que permitia sobreviver às tempestades que assolavam a tona de água. Todavia, e mesmo sem ter grandes noções de hidrologia, penso que convém não esquecer que, mesmo nas águas mais profundas existem correntes subaquáticas, por vezes coexistindo em diferentes profundidades, com diferentes velocidades ou mesmo em diferentes direcções.

\section{BIBLIOGRAFIA}

Agullar Saenz, A.; Guichard, P. 1993: Villes romaines d'Estremadure: Doña Maria, La Sevillana et leur environment. Madrid, Casa de Velazquez, (Collections de la Casa de Velazquez 43).

AlarCÃo, J. de, 1998: A paisagem rural romana e alto-medieval em Portugal. Conimbriga, Vol. XXXVII, Coimbra, 89-119.

ALmeIDA, D. F. de, 1962: Arte visigótica em Portugal. O Arqueólogo Português, 2. série, Vol. 4, Lisboa, 5-278.

ARCE, J., 2002: Mérida tardorromana (300-580 d.C.). Cuadernos Emeritenses 22, Mérida, Museo Nacional de Arte Romano.

BoISSELIER, S., 1999: Naissance d'une identité portugaise. La vie rurale entre Tage et Guadiana de I'Islam à la Reconquête (Xe-XIVe siècles). Lisboa, Imprensa NacionalCasa da Moeda.

BRown, P., 1978: The making of Late Antiquity. Cambridge.

- 1995: La Toge et la Mitre. Le monde de l'antiquité tardive. Paris, Thames \& Hudson.

BuENACASA P. C., 1997: La decadencia y cristianización de los templos paganos a lo largo de la Antigüedad Tardia (313-423). www.ub.es/grat/grat/32.htm.

Cameron, A., 1998: El mundo mediterráneo en la Antiguedad Tardia 395600. Barcelona.

CARDIm RibeiRo, J., 1982-1983: Estudos históricoepigráficos em torno da figura de L. Iulius Maelo Caudicus. Sintria vol. III (1), Sintra, 151476.

- 2002: Endovellicus. In: Cardim Ribeiro (dir) Religiões da Lusitânia. Loquuntur Saxa. Lisboa, Museu Nacional de Arqueologia, 79-90.

CARneiro, A., 2002: "0 fim do Império e a cristianização no território da civitas ammaiensis: mudança e continuidade no concelho de Fronteira", Ibn Maruan, Marvão, 135-157.

- 2004: Povoamento romano no concelho de Fronteira. Câmara Municipal de Fronteira/Câmara Municipal de Cascais/Edições Colibri.

Chavarria Arnau, A., 2004a: Considerazioni sulle fine delle ville in 0ccidente. Archeologia Medievale XXXI, Firenze, 7-19.

- 2004b: Monasterios, campesinos e villae en la Hispânia visigoda: la trágica historia del Abad Nancto. C. Balmelle, P. Chevallier e G. Ripoll (ed.) Mélanges d'Antiquité Tardive (II) De Ínfima Antiqvitate Stvdiola in honorem Noël Duval, Brepols Publishers, 113-125.
CUNHA, M., 2004: Silveirona: do mundo funerário romano à Antiguidade Tardia. Sete décadas depois. Dissertação de Mestrado em PréHistória e Arqueologia apresentada à Faculdade de Letras da Universidade de Lisboa, Lisboa [policopiado].

Deus, A. de; Louro, H.; VianA, A., 1955: Apontamentos de estações romanas e visigóticas da região de Elvas (Portugal). III Congresso Arqueologico Nacional (Galicia 1953). Zaragoza, 568-578.

Frade, H., CAetano, J. C., 1993: Ritos funerários romanos no nordeste alentejano. Actas do // Congresso Peninsular de História Antiga. Coimbra, Faculdade de Letras da Universidade de Coimbra, 847-873.

FRESCO DE ALMEIDA, M. A., 1987: Escultura arquitectónica e funerária dos séculos IV ao VIII, a Sul do Tejo. Dissertação final de Mestrado, em História da Arte, apresentada na Faculdade de Ciências Sociais e Humanas da Universidade Nova de Lisboa, Lisboa, UNL, 2 vols. [dactilografado].

Fuentes Dominguez, A., 1995: Extremadura en la tardia antiguedad. Extremadura Arqueologica IV, Badajoz, 217-237.

GodoY FERnÁNDEZ, C., 1995: Arqueología y liturgia: Iglesias hispanicas (siglos IV al VIII). Barcelona, Universitat de Barcelona.

Gorges, J. G., 1979: Les Villas HispanoRomaines: inventaire et problématique archéologiques. Paris, E. de Boccard (Publications du Centre Pierre Paris, 4).

HAUSCHILD, Th., 1984-1988: 0 edifício de culto do complexo de ruínas perto de Estói, na província da Lusitânia. Arqueologia e História (In memoriam Prof. Doutor D. Fernando de Almeida), Série $X_{1}$ vol. I/II, Lisboa, 123-150.

JoRge, A. M., 2002: L'épiscopat de Lusitanie pendant l' Antiquité tardive (III - VIII siécles). Lisboa, Instituto Português de Arqueologia (Trabalhos de Arqueologia 21).

LOPES, M. C., 2003: A cidade romana de Beja. Percursos e debates acerca da "civitas" de Pax lulia. Coimbra, Instituto de Arqueologia da Faculdade de Letras da Universidade de Coimbra, (Conímbriga/Anexos 3), 2 vols.

Lopez Quiroga, J., Rodriguez Martin, F. G., 2000-2001: El "final" de las villae en la Hispania. I. La transformación de las pars urbana durante la Antigüedad Tardia. Portvgalia, vol. XXIXXII, 137-190.

MACIEL, M. J., 1996: Antiguidade tardio e paleo-cristianismo em Portugal. Lisboa, Edição de Autor. 
MoRESCHINI, C., 1989: Movimenti filosofici della latinità tardoantica: problemi i prospettive. Metodologie della ricerca sulla tarda antichità, Atti del Primo Convegno dell'Associazione di Studi Tardoantiche, Napoli, M. D'Auria Editore, 89-120.

Oliveira, C.; Carvalho, A.; Almeida, , J. [no prelo] - Quinta das Longas (Elvas, Portugal): une uilla tardive á la périphérie de l'Empire romain. X Colóquio Internacional de la Association International pour l'Étude de la Mosaïque Antique, Museu Monográfico de Conímbriga (2005).

PereIRA, S., 2005: Da desagregação do Império ao período visigótico na freguesia de S. S. da Aramenha. In: OLIVEIRA, Jorge de (coord.) São Salvador da Aramenha. História e Memórias da freguesia. IbnMaruan n. ${ }^{\circ} 13,63-71$.

Perez LoSAdA, F., 1987: Sobre o concepto de villa no mundo romano. Cadernos de Arqueologia de Braga, série II, n. ${ }^{\circ}$ 4, Braga, 79-110.

Ramirez Sádaba, J. L.; Mateos Cruz, P., 2000: Catálogo de las inscripciones cristianas de Mérida, Mérida, MNAR (Cuadernos Emeritenses16), 2000
REIS, M. P., 1999: As termas públicas de Catania e a sua inserção urbana. Alguns parelelos [sic] na Lusitânia. IV Congreso de Arqueología Peninsular. Tomo IV, Zamora, Universidad Alacalá, 135-145.

SotTomAYOR, M., 1990: Romanos pero cristianos. A propósito de algunos cánones del Concilio de Elvira. Cristianismo y aculturación en tiempos del Imperio romano (Antigüedad y Cristianismo 7), Murcia, 1117.

VelÁzQuez, I., 2005: Hagiografia y culto a los santos en la Hispânia visigoda: aproximación a sus manifestaciones literárias. Cuadernos emeritenses 32, Mérida, Museo Nacional de Arte Romano.

VIANA, A., 1950: Contribuição para a arqueologia dos arredores de Elvas. Trabalhos de Antropologia e Etnologia, Vol. 12 (34), Porto, 289322

- 1959: Notas históricas, arqueológicas e etnográficas do Baixo Alentejo. Arquivo de Beja XVI, Beja, 3-48.

VIVES, J., 1947: Inscripciones cristianas de la España romana y visigoda. Barcelona, Instituto Jeronimo Zurita. 